Прокофьева В. Ю.

КУЛЬТУРНАЯ МЕТАФОРА МИР - ЗЕРКАЛО В ПОЭЗИИ РУССКИХ СИМВОЛИСТОВ

Прокофьева В. Ю.

V. Yu. Prokofeva

КУЛЬТУРНАЯ МЕТАФОРА МИР - ЗЕРКАЛО В ПОЭЗИИ РУССКИХ СИМВОЛИСТОВ

\title{
CULTURAL METAPHOR WORLD IS MIRROR IN POETRY OF RUSSIAN SYMBOLISTS
}

Прокофьева Виктория Юрьевна - доктор филологических наук, профессор кафедры журналистики Санкт-Петербургского государственного института кино и телевидения (Россия, Санкт-Петербург). E-mail:vicproc@rambler.ru.

Ms. Viktoria Yu. Prokofeva - Doctor of Philological Science, Full Professor, St. Petersburg State Institute of Cinema and Television (Russia, St. Petersburg). E-mail:vicproc@rambler.ru.

Аннотация. В статье анализируется использование культурной метафоры зеркала в поэзии русских символистов. Богатые смысловые возможности символа «зеркало» позволяют символистам наиболее полно выразить идею романтического двоемирия, используя ключевое слово для описания как видимой Вселенной (вертикальной и горизонтальной, сиюминутной и бесконечной), так и внутреннего мира человека (трансформация зеркала мира в зеркало души). Зеркало представлено в символисткой поэзии как метафоризатор, реализующий в трех общекультурных проекциях: зеркало как вещь, идея зеркальности и образ зеркала. Общекультурные мифологические коннотации образа зеркала (отражение, удвоение, симметрия, двойственность, слияние, бесконечность и т.п.) дополняются поэтами индивидуальной интерпретацией, что позволяет наиболее полно и разносторонне раскрыть в поэзии символистскую идею «всего во всем». Так «литературное зеркало» дополняет идеи «зеркал искусства».

Summary. The article analyzes the use of a «mirror» metaphor in the poetry of Russian Symbolists. Rich semantic possibilities of the mirror symbol allow the Symbolists to fully express the idea of a romantic dual conception of reality, using the keyword to describe both the visible Universe (vertical and horizontal, momentary and infinite) and the inner world of individual (the transformation of the mirror of the world into the mirror of the soul). The mirror is represented in the Symbolist poetry as a metaphor, realizing in three general cultural projections: a mirror as a thing, the idea of a mirror and the image of a mirror. The general cultural mythological connotations of the image of the mirror (reflection, doubling, symmetry, duality, fusion, infinity, etc.) are supplemented by poets with an individual interpretation, which allows us to reveal the symbolic idea of "everything in everything" in poetry in the most complete and diversified manner. Thus, the «literary mirror» complements the ideas of «mirrors of art».

Ключевые слова: метафора, зеркало, художественная картина мира, символизм, поэзия Серебряного века.

Key words: metaphor, mirror, artistic picture of the world, symbolism, poetry of the Silver Age.

УДК 882.086

Осмысление мира в терминах зеркала проходит через всю историю культуры. При этом на первый план выдвигаются то одни, то другие символические коннотации зеркала, в зависимости от того, в какую эпоху и применительно к какому объекту данный концепт используется в качестве метафоризатора. Акцентируется «то отражательная способность зеркала, то его свойство искажать, то удваивать или переворачивать мир, то нереальность зеркального изображения; однако то постоянство и настойчивость, с какою самые различные мыслители в самых различных временных и пространственных рамках прибегают к образу зеркала, поистине поразительна. Круг объектов, интерпретируемых посредством «зеркальной метафоры, чрезвычайно широк» [4, 110], О. А. Дегтярева, исследуя в своей диссертации «культурные опосредования» зеркала в контексте различных культурологических и философских концепций, приходит к выводу, что «зеркало даёт нам одно из первых таких опосредований в образе. Изучение разнообразных смыслов и значений зеркала в истории культуры является опытом рассмотрения этого предмета как одного из явлений, присутствующих в культуре и сопровождающих человека» [5, 4]. Метаморфозы образа зеркала в 
истории культуры подробно исследованы в диссертации М. В. Рон, рассмотревшей феномен зеркала «в трех проекциях: зеркало-вещь, идея зеркала и зеркальности, образ зеркала» $[7,5]$. При всем многообразии работ о семиотике зеркала в истории культуры объектом их становится, как правило, «зеркало искусства», «зеркалу литературы» уделяется меньше внимания, хотя исследование «литературных зеркал» существенно дополнит культурологическое знание. Монографически об этой проблеме высказался Абрам Вулис в книге «Литературные зеркала» (М., 1991), где тем не менее в поле зрения попадают не только и не столько зеркала литературных произведений. Мы решили обратиться к поэзии русских символистов, воплотивших культурную метафору зеркала во всеобъеме.

Вслед за романтиками символисты исповедовали идею двоемирия, в лаконичной поэтической форме эта мысль оформилась в стихотворении Вл. Соловьева, ставшем символистским манифестом:

Милый друг, иль ты не видишь, Милый друг, иль ты не слышишь,

Что все видимое нами -

Только отблеск, только тени

Что житейский шум трескучий -

От незримого очами.

Только отклик искаженный

Торжествующих созвучий.

Здесь уже начало оформляться понимание символистами мира материального как отблеска и отклика иного мира, которое вылилось в поэтике всего направления в метафору мир - зеркало.

Поэзия символизма активно использует символику зеркала для представления своей, одновременно традиционно-мифологической и новаторски интерпретационной картины мира. Поэты находят богатые смысловые возможности символа «зеркало» для описания своего художественного мира, самым же «зеркальным» оказывается Вяч. Иванов.

Зеркало как предмет домашний (B квартире прибрано. Белеют зеркала. - Анненский) или магический, мистически загадочный, в символистской поэзии упоминается нечасто:

Мы Титаны. Он младенец. Вот он в зеркало взглянул:

В ясном зеркале за морем лик его, делясь, блеснул!

Мы подкрались, улучили полноты верховной миг,

Бога с богом разлучили, растерзали вечный лик. (Вяч. Иванов)

Чаще символисты используют слово зеркало не в прямом его значении, их интересует не столько сам предмет, сколько его способность отображать и отображаться; зеркало как знак зеркальности оказывается одной из доминант в символистской картине мира, об этом свидетельствует, например, уподобление зеркальности поэтического искусства:

В красоте музыкальности,

Как в недвижной зеркальности,

Я нашел очертания снов,

Как растенья под глыбою льдов. (Бальмонт)

В романтической философии искусства «художник-демиург господствует над миром, сконцентрированным по принципам «магического идеализма», причем предметы этого мира - лишь объективизированные рефлексии субъекта. Эти же принципы вновь выявляются в «магическом символизме», где также тотализируется принцип зеркальности. $<\ldots$..> В раннем символизме человек находится «между двумя мирами», он колеблется между различными уровнями рефлексии своего собственного самосознания, однако если в романтизме царит надежда на достижение «трансцендентальной самости» (Новалис), то в нигилистическом раннем символизме доминирует чистое состояние между» $[8,110]$. Поэтому видимая Вселенная в поэзии символизма предстает в образе двух зеркал, обращенных друг к другу. «Верх» - «верхнее зеркало» - прозрачность небосвода и «низ» - «нижнее зеркало» - «зеркало вод» (озера, моря и т.д.):

Воды мятежились, буря гремела, - но вот

В водной зеркальности дышит опять небосвод. (Бальмонт)

Мистическая ассоциативная аура слов зеркало, зеркальность связывает их не только с дневным отражением, но и с ночной водой и ночным небом: 
Прокофьева В. Ю.

КУЛЬТУРНАЯ МЕТАФОРА МИР - ЗЕРКАЛО В ПОЭЗИИ РУССКИХ СИМВОЛИСТОВ

То вспыхивал, то гас дотла Прозрачность!..

Сей пересвет необычайный, Что полночь в твой сумрак уронит,

И сумрачные зеркала В бездонности тонет зеркальной.

Свой омут обличали тайный. (Вяч. Иванов)

В символистском представлении пространства два мира подобны живым существам, поэтому им присуща способность смотреть друг на друга в зеркало - границу между ними:

Порою... Порою, темна,

Глядела пустынная мгла

Под нашей ладьей в зеркала

Стесненных дворцами лагун

$$
\text { ...... }
$$

И в узких каналах со дна

Глядела другая луна. (Вяч. Иванов)

Символистская Вселенная симметрична, как любое живое существо:

Высот недвижные озера -

Отверстые зеницы гор-

Мглой неразгаданного взора

Небес глубокий мерят взор. (Вяч. Иванов)

Высота «низа» равна глубине «верха», общее же - в неразгаданности, мутности того и дру-

гого. Если нижний мир смотрит на верхний, то последний отражается в первом, имеющем естественную границу:

Я шел безбрежными пустынями

И видел бледную Луну,

Она плыла морями синими

И опускалася ко дну. (Бальмонт)

Пространственная противоположность двух миров в совокупности с идеей их одушевленности рождает ассоциативный образ соединения, брачного союза этих стихий. Образ этот имеет истоки в греческой мифологии: Гея (Земля), породившая из себя Урана-небо и Понта-моря, поочередно вступала с ними в брачный союз, в результате которого появлялись титаны, циклопы, чудовищные существа, а также - Афродита:

Опрокинулось Небо однажды, и блестящею кровью своей

Сочеталось, как в брачном союзе, с переменною Влагой морей.

И на миг вероломная Влага с этой кровью небесною слита,

И в минутном слияньи двух светов появилася в мир Афродита. (Бальмонт)

Символистский мотив моментального преобразования мира реализуется в поэтическом тексте метафорическим представлением опрокинутых пространств:

Кто опрокинул надо мной

Полночных мук беззвездный купол... (Ходасевич)

Присутствие Бога в верхнем мире, как правило, в символистской картине мира явно не выражено. Пожалуй, наиболее ярко это эксплицируется опять же в поэзии Вяч. Иванова, где зрительное отражение дополняется слуховым:

Пустых зеркал стоомутная мрачность

В ста бликах пьет дня первый робкий блик,

В откликах рассветный множит клик.

Глядится Бог в свой мир, и мир - прозрачность. (Вяч. Иванов)

Гораздо чаще наблюдателем «всемирной зеркальности» и «мировой симметрии» становится сам поэт, открывающий читателю законы миробытия: Жизнь - отражение лунного лика в воде, Жизнь - трепетание моря под властью луны (Бальмонт). Симметричность мироздания представлена в поэтических текстах символистов и идентичными синтаксическим конструкциями, описывающими «верх» и «низ»: 
И ангел поднял в высоту

Звезду зеленую одну,

И стало дивно на мосту

Смотреть в такую глубину,

В такую высоту. (Блок),

и разнообразными лексическими средствами:

а) употреблением предлога над по отношению к пространству небесному в том случае, когда описывается его водное отражение: Смотрю на море... Стою над пропастью - над небесами И улететь к лазури не могу (3. Гиппиус);

б) употреблением по отношению к небесному пространству слов, ассоциативно связанных с глубиной, а не высотой: Разъята надо мною пасть (ночное небо - В.П.)... Ее пророческое дно Мой путь созвездьями означит (А. Белый);

в) присутствием в «земных» и «небесных» описаниях слов одного семантического поля: Жемчужные звезды повисли, Внизу - ожерелье огней (Брюсов);

г) через метафору, где зеркальность проявляется лишь на ассоциативном уровне: Лес опрокинут в реке.

Зеркальное отражение может быть передано с помощью разнообразных предметов: «...обратим внимание на исключительное многообразие и многочисленность окружающих человека «зеркал», т.е. отражающих поверхностей, - от собственно зеркал и окон до озер и луж, снежинок, кусочков каменного угля, бутылочного горлышка на плотине в лунную ночь: все они создают «разрывы» в зримой вещественной ткани мира, а в мифологизирующем плане могут рассматриваться как окна в иной мир» $[6,11]$. Символисты стремятся к изображению «всякой и всяческой» зеркальности. Например, Вяч. Иванов дополняет вышеперечисленный ряд еще одним «зеркалом»: способностью отражать «верхний мир» поэт наделяет не только воду, но и плоды: Персики зардели огоньками, Отразили зеркальцами Солние. Характерно, что у поэта персики - не маленькие солнца, они лишь в какой-то момент способны отразить многими «зеркальцами» одно Солнце (в зависимости от освещенности и благодаря цветовому сходству).

В акустической сфере «эхо» является тем же, чем «отражение» в сфере визуальной, поэтому символисты в поисках разнообразных способов представления инварианта двоемирия находят и его «слуховой» вариант:

Цветок и воздух, смущенный эхом,

То полный плачем, то полный смехом.

Цветок нарцисса, и звук заветный,

Ответом вставший, но безответный. (Бальмонт)

«Чрезвычайно часто зеркало выступает в роли модели для осмысления сознания, психики. Отражательная природа того и другого дает богатую основу для их сближения по самым разным основаниям» $[4,110]$. В картине мира символистов зеркальность - свойство не только внешнего мира, но и внутреннего мира человека. Связь человека и мира - отражение - проявляется в трансформации зеркала в зеркало души («внутреннее зрение»):

Не так ли ты,

В тиши,

Мерцало,

Алтарь мечты,

Зрящей души

Моей зерцало...(Вяч. Иванов)

Метафора зеркала используется и при описании такого состояния человека, как мечтание:

Виденья дней, как будто бы не бывших,

Встают, как сказка, в зеркале мечты. (Бальмонт)

Появление в тексте ТЫ-персонажа сопровождается неизбежным «удвоением» зеркальности. Два человека - два мира, две бездны, две зеркальности. Сочетание выражений чужая душа потемки и блуждать в потемках позволило раннему символисту К. Льдову скомбинировать ме- 
Прокофьева В. Ю.

тафору «двойного зеркала» с метафорой блуждания в «лабиринте души», в результате родилось типично символистское представление Себя и Другого («всё во всём»), внутреннего мира как отраженной бездны:

Как в лабиринте двух зеркал,

В себе мой дух тебя искал, -

И ты, склонившись в полусне,

Себя увидела во мне.

«Зеркало души» преображается у символистов в «зеркало жизни»:

Пора сказать: я выпил жизнь до дна,

Что пенилась улыбками в кристалле,

И ты стоишь в пустом и гулком зале,

Где сто зеркал, и в темных ста - одна. (Вяч. Иванов)

Причем, если у души человека одно зеркало, то в жизни человека их - сто. Любые жизненные моменты - своеобразные зеркала одного зеркала - души (ср. название одного из циклов стихотворений Вяч. Иванова «Speculum Speculorum» - «Зеркало зеркал»). Да и сам человек в понимании символистов отождествляется либо с зеркалом, либо - с отраженьем:

Я зеркало ликов земных

И собственной жизни бездонной. (Бальмонт)

К. Бальмонта можно назвать вторым после Вяч. Иванова символистом по частотности использования в творчестве «зеркальных» метафор. Интересно, что в критических статьях о Бальмонте символисты применяют и к описанию его поэтического творчества метафору зеркала. Так, А. Белый называет поэзию Бальмонта «зеркалом», где в вечернем свете сверкают бесчисленные «драгоценные камни», т.е. использует метафору зеркала со всеми ее ассоциациями (зеркало гладкая поверхность и в то же время бездна; отблеск, отражение и т.п.): «Бальмонт - последний русский великан чистой поэзии. <...> Луч заходящего солнца, упав на гладкую поверхность зеркала, золотит его бездной блеска. <..> Бальмонт - сияющее зеркало эстетизма, горящее сотнями яхонтов» $[2,402]$. И. Анненский разграничивает поверхностное самоописание Бальмонта и подлинное подсознательное «Я» поэта, опять же через метафору зеркала: «В стихотворении Бальмонта «Мне чужды ваши рассужденья» идеал ненарушенной цельности «Я» переживается как замкнутость, которая парадоксальным образом сочетается с растворением себя в мимолетных впечатлениях. Сквозь зеркальную поверхность самосознания просвечивает «дно», темный мир бессознательного» $[1,110]$.

Зеркалом мира символисты называют не всякого человека, но лишь Поэта, способного «отражать» своим творчеством:

Пусть миражного круженья

Через миг погаснут светы...

Пусть я - радость отраженья,

Но не то ль и вы, поэты? (Анненский)

Поэт связан с двумя мирами своим творчеством, К. Бальмонт сравнивает поэзию со свечой, стоящей между двумя зеркалами и бесконечно в них отражающейся: «Зеркало в зеркало, сопоставь две зеркальности, и между ними поставь свечу. Две глубины без дна<... обогатят пламя свечи и соединятся им в одно. Это образ стиха» $[2,5]$.

Окказиональный образ находим в лексическом самоопределении В. Ходасевича: $Я$ звук, $я$ вздох, я зайчик на паркете - солнечный зайчик как отражение через зеркало паркета.

Зеркало в символисткой картине мира может соотноситься не только с реальным локусом, но и с гипотетическим. Отсюда метафора «зеркала памяти»:

То Памяти река. Склонись у вод -

И двойников живых своих увидишь:

Твой каждый лик, и больше твой, чем тот,

Что ты, стыдясь, несешь и ненавидишь. (Вяч. Иванов) 
Здесь «важна горизонтальность: зеркало меняет верх на низ, высоту на глубину, как бы нейтрализуя соответствующую оппозицию, совмещая ее полюсы, - что в точности соответствует известной в мистической традиции модели души, именно глубины которой причастны к "божескому началу"» $[6,12]$. Использованы и то свойство горизонтального зеркала, что над ним надо склониться, т.е. принять молитвенную позу, чтобы увидеть свое отражение (или свои отражения), и та культурно-мифологическая ассоциация, неизбежно рождающаяся в сознании читателя Нарцисс:

Все виденья оконченного дня,

Все минутности предметов и людей,

Мне все равно, что скрыто там на дне,

Самого себя бесплотным двойником

Вижу в ясной успокоенной воде.

Я в зеркале поверхности красив.

Поверхность отражает выси гор,

Измены дня.

Таким образом, в своей поэзии символисты, актуализируя различные значения слова зеркало и используя традиционно-мифологические и собственно символистские коннотации, представляют на основе метафоры мир - зеркало особое художественное пространство, свойственное именно этому направлению.

\section{ЛИТЕРАТУРА}

1. Анненский, И. Ф. Книга отражений / И. Ф. Анненский. - М., 1979. - 679 с.

2. Бальмонт, К. Поэзия как волшебство / К. Бальмонт. - М.: Скорпион, 1915. -93 с.

3. Белый, А. Символизм как миропонимание / А. Белый. - М., 1994. - 528 с.

4. Борухов, Б. А. «Зеркальная» метафора в истории культуры / Б. А. Борухов // Логический анализ языка. Культурные концепты. - М., 1991. - С. 109-116.

5. Дегтярева, О. А. Зеркало как общекультурный феномен: автореф. дисс. ... канд. культурологии / Дегтярева Ольга Александровна. - СПб., 2002. - 24 с.

6. Левин, Ю. И. Зеркало как потенциальный семиотический объект / Ю. И. Левин // Ученые записки Тартуского государственного университета. Вып. 831 (Труды по знаковым системам. Т. 22: Зеркало. Семиотика зеркальности). - Тарту, 1988. - С. 6-24.

7. Рон, М. В. Метаморфозы образа зеркала в истории культуры: автореф. дисс. ... канд. культурологии Рон Мария Витальевна. - СПб., 2004. - 22 с.

8. Ханзен-Лёве, О. А. Русский символизм: Система поэтических мотивов. Ранний символизм / О. А. Ханзен-Лёве. - СПб., 1999. - 813 с. 